\title{
Modeling of coagulation, curd firming, and syneresis of goat milk from 6 breeds
}

\author{
Michele Pazzola, ${ }^{*}$ Giorgia Stocco, ${ }^{* 1}$ Pietro Paschino, ${ }^{*}$ Maria L. Dettori, ${ }^{*}$ Claudio Cipolat-Gotet, †‡ \\ Giovanni Bittante, $†$ and Giuseppe M. Vacca* \\ *Department of Veterinary Medicine, University of Sassari, via Vienna 2, 07100 Sassari, Italy \\ †Department of Agronomy, Food, Natural Resources, Animals and Environment (DAFNAE), University of Padova, viale dell'Università 16, \\ 35020 Legnaro (PD), Italy \\ ‡Department of Veterinary Science, University of Parma, Via del Taglio 10, 43126 Parma, Italy
}

\begin{abstract}
Traditional milk coagulation properties are used to predict the suitability of milk for cheese-making. In bovine and ovine species, the introduction of the concept of curd firming over time, continuously recorded by a lactodynamograph during prolonged tests, provides additional information about milk coagulation, curdfirming, and syneresis processes. The aims of present study were (1) to test the adaptability of a 4-parameter curd-firming model in the assessment of goat milk (also comparing published data of other species); (2) to describe variability of coagulation, curd firming, and syneresis processes among individual goat milk samples; (3) to quantify the effects of farm and animal factors (breed, parity, and stage of lactation); and (4) to compare 6 goat breeds for their model parameters. Milk samples from 1,272 goats reared in 35 farms were collected. Goats were of 6 breeds: Saanen and Camosciata delle Alpi for the Alpine type; and MurcianoGranadina, Maltese, Sarda, and Sarda Primitiva for the Mediterranean type. During a lactodynamographic analysis (60 min), 240 measures of curd firmness (mm) were recorded for each milk sample. The modeling of curd firming allowed us to achieve the rennet coagulation time estimated on the basis of all the data points (min); the curd firming and the curd syneresis instant rate constants; the asymptotical potential value of curd firming; the actual maximum curd firmness; and the time at which the curd firming maximum level is attained. Modeling parameter data were analyzed using a linear mixed model. Comparison with other dairy species showed several differences: goat milk coagulated later than sheep but earlier than bovine, and curd firming and curd syneresis instant rate constants were greater
\end{abstract}

Received January 5, 2018.

Accepted March 24, 2018

${ }^{1}$ Corresponding author: giorgiastocco12@gmail.com in small ruminants. Modeling parameters of goat milk were mostly affected by the farm effect ( $37 \%$ of the total variance, on average) compared with the results found for bovine and ovine samples, and this was probably attributable to the marked differences among goat farming systems. Small differences were demonstrated between Alpine and Mediterranean breeds, but the time of maximum curd firmness was lower in MurcianoGranadina compared with Maltese, Sarda, and Sarda Primitiva. Sarda and Sarda Primitiva were very similar and exhibited the most favorable coagulation properties of milk. For almost all the model parameters, the direct effect of breed was increased after correction for milk yield and composition. In conclusion, this approach allowed us to fully depict the effects of the different factors on coagulation of goat milk, and clarified the different renneting pattern among goat breeds, and with other species. Results could be used for the valorization of goat dairy products, also when these are linked to particular local breeds, and to stimulate further studies about relationships between coagulation and cheese-making traits.

Key words: milk coagulation, curd firming, lactodynamograph, goat

\section{INTRODUCTION}

The contribution of goat milk production to the social and nutritional fields is unquestionable, especially in many developing countries, like those in the Mediterranean, Middle East, Eastern Europe, and South America (Selvaggi et al., 2014). Nowadays, the use of goats in abandoned and degraded areas contributes to the ecosystem, preventing wildfires and providing defense against hydrogeological instability (Marsoner et al., 2017). Moreover, goats fit well to extreme environments and are able to provide high-quality food under diverse climatic conditions (Silanikove, 2000). In developed countries of Europe, Oceania, and North and South America, goat milk production has gradually 
assumed an economic relevance, especially due to the production of different types of labeled cheese (Pirisi et al., 2007), which are often characterized by high market prices because they are properly selected as delicatessen food (Park et al., 2007; Silanikove et al., 2010).

Because the large majority of goat milk is used for the production of cheese, a detailed characterization of its coagulation ability can be very useful for dairy industries. The traditional milk coagulation properties [MCP: rennet coagulation time (RCT, min), curd firming time $\left(\mathbf{k}_{\mathbf{2 0}}, \mathrm{min}\right)$, and curd firmness $\left(\mathbf{a}_{\mathbf{3 0}}, \mathbf{m m}\right)$ ] are single-point parameters introduced to study and evaluate the suitability of bovine milk used to produce cheese. As MCP could affect cheese characteristics (Martin et al., 1997), they are fundamental for cheese labeled with Protected Designation of Origin (PDO) in the European Union (Bertoni et al., 2005) and in several dairy chains in which they are used in milk quality payment systems (Bittante et al., 2011).

The MCP have been frequently determined by mechanical lactodynamographic instruments that measure curd formation and firmness during a 30-min test (McMahon and Brown, 1982). Recently, the synergic possibility to extend the MCP analysis beyond $30 \mathrm{~min}$ (Cipolat-Gotet et al., 2012) and to model the entire output of lactodynamograph analyses by introducing the concept of curd firming over time $\left(\mathbf{C F}_{\mathrm{t}}\right)$ pattern provides additional information about milk coagulation, curd firming, and syneresis processes. That approach has been already applied in dairy cows (Malchiodi et al., 2014; Stocco et al., 2017) and used to mimic Grana Padano PDO coagulation process (Stocco et al., 2015). It includes the asymptotic potential value of curd firmness at an infinite time $\left(\mathbf{C F}_{\mathbf{P}}, \mathbf{m m}\right)$ and the curdfirming instant rate constant $\left(\mathbf{k}_{\mathrm{CF}}, \% / \mathrm{min}\right)$. The $\mathrm{RCT}$ is not predicted as a single point measurement but from the result of modeling all data available $\left(\mathbf{R C T}_{\mathbf{e q}}, \mathrm{min}\right)$. Moreover, as proposed by Bittante et al. (2013), the modeling of data obtained using prolonged lactodynamographic tests permits also to gain information of the syneresis instant rate constant $\left(\mathbf{k}_{\mathrm{SR}}, \% / \mathrm{min}\right)$ that tends to reduce curd firming beyond a maximum value $\left(\mathbf{C F}_{\max }, \mathbf{m m}\right)$ after a given time interval $\left(\mathbf{t}_{\max }, \mathrm{min}\right)$. Modeling of $\mathrm{CF}_{\mathrm{t}}$ has been studied also in sheep milk from different Alpine breeds (Bittante et al., 2014) and from the Sarda (Vacca et al., 2015).

Those studies on cow and sheep milk indicate the limitations of the traditional MCP and the need for modeling of the curd firming information. Indeed, the sole investigation of the traditional MCP, with the standard 30-min lactodynamographic analysis, causes an inaccurate interpretation of the processes of milk coagulation, curd firming, and syneresis.
In both developed and developing countries, to achieve the increase of goats' productive performances, animals of foreign specialized breeds have been imported with the aim to replace or to be crossed with autochthonous genetic types (Dubeuf and Boyazoglu, 2009; Vacca et al., 2016). However, those strategies do not take into account the effect of the environment on imported animals, the differences in milk coagulation, curd firming, and syneresis of different breeds of goat in the local conditions. The differences among goat breeds in relation to traditional MCP have been already investigated (Vacca et al., 2018), but the existing literature does not include any information regarding the $\mathrm{CF}_{\mathrm{t}}$ modeling parameters in goat species. For these reasons, we extended the objective of our survey on 6 different goat breeds to achieve the following aims: (1) to test the adaptability of a 4-parameter curd-firming model in the assessment of goat milk, also comparing published data from other species; (2) to describe variability of coagulation, curd firming, and syneresis processes among individual goat milk samples; (3) to quantify the effects of farm and animal factors (breed, parity, and stage of lactation) on coagulation pattern; and (4) to compare 6 goat breeds for their $\mathrm{CF}_{\mathrm{t}}$ modeling parameters.

\section{MATERIALS AND METHODS}

\section{Farm Characteristics and Milk Sampling}

The study involved 1,272 goats reared in 35 farms (24 single breeds and 11 multi-breeds), distributed over the whole island of Sardinia (Italy). Farms were selected among those officially registered in the flock books and recording system of provincial associations of goat breeders. Six different breeds were sampled: Saanen (Sa) and Camosciata delle Alpi (CA) for the Alpine type; and Murciano-Granadina (MG), Maltese (Ma), Sarda (Sr), and Sarda Primitiva (SP) for the Mediterranean type.

Individual milk samples $(200 \mathrm{~mL} /$ goat $)$ were collected during the afternoon milking (1 sampling day for each farm), stored at $4^{\circ} \mathrm{C}$ and analyzed within $24 \mathrm{~h}$ after collection. Daily milk yield (dMY) was recorded as the total yield of morning plus evening milking of the same day of sampling. Details about farms, number of sampled animals at each farm, parity, and stage of lactation of goats and sampling procedures are described in Vacca et al. (2018).

\section{Analysis of Milk Samples}

Analysis of milk composition and MCP are described in Vacca et al. (2018). In brief, MilkoScan FT6000 
(Foss Electric A/S, Hillerod, Denmark) was used to measure fat, protein, lactose, and $\mathrm{pH}$. Daily fat and protein yield (dFPY, g/d) was calculated as the sum of fat and protein percentage multiplied by the dMY; a Fossomatic 5000 (Foss Electric A/S) was used to assess SCC, then log-transformed to SCS $\left[\log _{2}(\mathrm{SCC} \times\right.$ $\left.\left.10^{-5}\right)+3\right]$. Total bacterial count was analyzed by a BactoScan FC150 analyzer (Foss Electric A/S) and log-transformed bacterial count $\left[\mathbf{L B C}=\log _{10}\right.$ (total bacterial count/1,000)].

\section{Modeling Curd Firmness and Syneresis}

Coagulation of milk samples was assessed by a Formagraph (Foss Italia S.P.A., Padova, Italy); the test was prolonged up to $60 \mathrm{~min}$ using the procedure reported in detail by Pazzola et al. (2014a). In brief, $10 \mathrm{~mL}$ of each sample of raw milk was heated to $35^{\circ} \mathrm{C}$ and mixed with $200 \mu \mathrm{L}$ of the rennet solution [Hansen Naturen Plus 215 (Pacovis Amrein AG, Bern, Switzerland), with $80 \pm 5 \%$ chymosin and $20 \pm 5 \%$ pepsin; 215 international milk clotting units $/ \mathrm{mL}$; diluted to $1.2 \%$ (wt/vol) in distilled water to reach the final value of 0.0513 international milk clotting units/mL of milk].

Every $15 \mathrm{~s}$ during testing, the Formagraph apparatus recorded the width $(\mathrm{mm})$ of the oscillatory graph of the pendula immerged in the wells filled with milk samples after rennet addition. Consequently, 240 curd firming individual point observations were recorded for each individual milk sample. The differences in $\mathrm{CF}_{\mathrm{t}}$ pattern of the individual goats were measured by a 4 -parameter model (Bittante et al., 2013):

$$
\mathrm{CF}_{\mathrm{t}}=\mathrm{CF}_{\mathrm{P}} \times\left[1-e^{-\mathrm{k}_{\mathrm{CF}} \times\left(\mathrm{t}-\mathrm{RCT}_{\mathrm{eq}}\right)}\right] \times e^{-\mathrm{k}_{\mathrm{SR}}} \times{ }^{\left(\mathrm{t}-\mathrm{RCT}_{\mathrm{eq}}\right)},
$$

where $\mathrm{CF}_{\mathrm{t}}$ is curd firmness at time $\mathrm{t}(\mathrm{mm}) ; \mathrm{CF}_{\mathrm{P}}$ is the asymptotical potential value of curd firming at an infinite time in absence of syneresis $(\mathrm{mm}) ; \mathrm{k}_{\mathrm{CF}}$ is the curd-firming instant rate constant $(\% / \mathrm{min}) ; \mathrm{k}_{\mathrm{SR}}$ is the syneresis instant rate constant $(\% / \mathrm{min})$; and $\mathrm{RCT}_{\text {eq }}$ is $\mathrm{RCT}$ estimated by the $\mathrm{CF}_{\mathrm{t}}$ equation on the basis of all data points (min).

\section{Statistical Analysis}

To avoid convergence and estimation problems, the procedure by Bittante et al. (2013) was modified according to Cipolat-Gotet et al. (2018) to include curd firming measurements up to 45 min after the addition of rennet (180 records for each individual milk sample, 1 every $15 \mathrm{~s})$. The asymptotical $\mathrm{CF}_{\mathrm{P}}$ was calculated by multiplying $\mathrm{CF}_{\max }$ by 1.15 , which is the coefficient resulting from the linear regression between $\mathrm{CF}_{\mathrm{P}}$ and $\mathrm{CF}_{\max }$ values obtained from a preliminary analysis, in which these parameters were estimated by using the procedure proposed by Bittante et al. (2013). The others $3 \mathrm{CF}_{\mathrm{t}}$ model parameters $\left(\mathrm{RCT}_{\mathrm{eq}}, \mathrm{k}_{\mathrm{CF}}\right.$, and $\left.\mathrm{k}_{\mathrm{SR}}\right)$ were estimated by a curvilinear regression using the PROC NLIN of SAS software (version 9.4, SAS Institute Inc., Cary, NC). The parameters of each individual equation were estimated using the Marquardt iterative method (350 iterations and a $10^{-5}$ level of convergence) according to Bittante (2011).

Resulting parameters from coagulation modeling were then analyzed using a MIXED procedure (SAS Institute Inc., Cary, NC), according to the following model:

$$
\begin{gathered}
\mathrm{y}_{\text {mnopqr }}=\mu+\text { Farm }_{\mathrm{m}}+\text { Breed }_{\mathrm{n}}+\text { Parity }_{\mathrm{o}}+\text { DIM }_{\mathrm{p}} \\
+ \text { Pendulum }_{\mathrm{q}}+\mathrm{e}_{\mathrm{mnopqr}},
\end{gathered}
$$

where $\mathrm{y}_{\mathrm{mnopqr}}$ is the observed trait $\left(\mathrm{RCT}_{\mathrm{eq}}, \mathrm{k}_{\mathrm{CF}}, \mathrm{k}_{\mathrm{SR}}\right.$, $\mathrm{CF}_{\mathrm{P}}, \mathrm{CF}_{\max }$, and $\left.\mathrm{t}_{\max }\right) ; \mu$ is the overall intercept of the model; Farm $_{\mathrm{m}}$ is the random effect of the mth farm (m $=1$ to 35); Breed $_{n}$ is the fixed effect of the nth breed ( $\mathrm{n}=\mathrm{Sa}, \mathrm{CA}, \mathrm{Ma}, \mathrm{MG}, \mathrm{Sr}$, and SP); Parity ${ }_{\mathrm{o}}$ is the fixed effect of the oth parity [o $=1$ to 3 ; class 1 : first and second (392 samples); class 2: third and fourth (460 samples); class 3: $\geq$ fifth (420 samples)]; $\mathrm{DIM}_{\mathrm{p}}$ is the fixed effect of the pth class of DIM $[\mathrm{p}=1$ to 4 ; class 1 : $<80$ d (329 samples); class 2: 80-120 d (350 samples); class 3: 121-160 d (352 samples); class 4: >161 d (241 samples)]; Pendulum ${ }_{q}$ is the random effect of the qth measuring unit of the Formagraph instrument $(\mathrm{p}=1$ to 10$)$; $\mathrm{e}_{\text {mnopqr }}$ is the random residual $\sim N\left(\mathbf{0}, \sigma^{2}\right.$ e), where $\sigma^{2}$ is the residual variance.

The following orthogonal contrasts were used to estimate differences among breeds: (1) Alpine type (Sa and $\mathrm{CA}$ ) versus Mediterranean type breeds (MG, Ma, Sr, and SP); (2) between the 2 Alpine type breeds (Sa vs. CA); (3) within the 4 Mediterranean type breeds (MG vs. Ma, Sr, and SP); (4) within the 3 Italian breeds (Ma vs. Sr and PR); and (5) comparison between the 2 local breeds from Sardinia (Sr vs. SP). Orthogonal contrasts were also estimated among goats with different order of parity (1st and 2nd vs. $\geq 3$ rd and 4th; 3rd and 4th vs. $\geq 5$ th), and for DIM effect (linear, quadratic, and cubic).

To obtain a proper estimation of total variance of breed, model [1] was modified in model [2], treating breed as a random effect residual. Then, model [2] was modified in model [3], which included linear covariates of dMY, fat \%, protein $\%$, lactose $\%, \mathrm{pH}, \mathrm{SCS}$, and $\mathrm{LBC}$ to assess the direct effect of the breed, without its indirect effect due to differences in milk yield and 
Table 1. Descriptive statistics of yield traits, chemical composition, and curd firming over time $\left(\mathrm{CF}_{\mathrm{t}}\right)$ equation parameters and derived traits

\begin{tabular}{|c|c|c|c|c|c|}
\hline Trait & No. of samples & Mean & $\mathrm{SD}$ & Skewness & Kurtosis \\
\hline \multicolumn{6}{|l|}{ Yield trait, kg/d } \\
\hline Daily milk yield & 1,257 & 1.85 & 1.09 & 0.71 & -0.18 \\
\hline Daily fat and protein yield & 1,256 & 0.14 & 0.07 & -0.05 & 0.59 \\
\hline \multicolumn{6}{|l|}{ Quality trait of milk } \\
\hline Fat, \% & 1,258 & 4.60 & 1.44 & 0.79 & 0.38 \\
\hline Protein, $\%$ & 1,251 & 3.61 & 0.55 & 0.54 & -0.19 \\
\hline Lactose, \% & 1,254 & 4.65 & 0.27 & -0.28 & 0.33 \\
\hline $\mathrm{pH}$ & 1,260 & 6.72 & 0.11 & 0.21 & 0.88 \\
\hline $\mathrm{SCS}^{1}$ & 1,271 & 5.79 & 2.01 & 0.09 & -0.41 \\
\hline $\mathrm{LBC}^{2}$ & 1,253 & 1.70 & 0.79 & 0.43 & -0.18 \\
\hline \multicolumn{6}{|l|}{$\mathrm{CF}_{\mathrm{t}}$ equation parameter ${ }^{3}$} \\
\hline $\mathrm{RCT}_{\mathrm{eq}}, \min$ & 1,234 & 13.9 & 4.4 & 0.84 & 0.93 \\
\hline $\mathrm{k}_{\mathrm{CF}}, \% / \min$ & 1,232 & 17.9 & 8.0 & 1.37 & 2.36 \\
\hline $\mathrm{k}_{\mathrm{SR}}, \% / \min$ & 1,226 & 0.62 & 0.51 & 2.08 & 4.18 \\
\hline $\mathrm{CF}_{\mathrm{P}}, \mathrm{mm}$ & 1,246 & 44.5 & 12.4 & -0.02 & -0.58 \\
\hline $\mathrm{CF}_{\max }, \mathrm{mm}$ & 1,246 & 39.4 & 11.0 & -0.02 & -0.58 \\
\hline $\mathrm{t}_{\max }, \min$ & 1,256 & 39.2 & 12.1 & 0.19 & -0.95 \\
\hline
\end{tabular}

${ }^{1} \mathrm{SCS}=\log _{2}\left(\mathrm{SCC} \times 10^{-5}\right)+3$.

${ }^{2}$ Logarithmic bacterial count $(\mathrm{LBC})=\log _{10}$ (total bacterial count/1,000).

${ }^{3} \mathrm{RCT}_{\mathrm{eq}}=$ rennet coagulation time estimated by $\mathrm{CF}_{\mathrm{t}}$ modeling; $\mathrm{k}_{\mathrm{CF}}=$ curd firming instant rate constant; $\mathrm{k}_{\mathrm{SR}}=$ syneresis instant rate constant; $\mathrm{CF}_{\mathrm{P}}=$ asymptotic potential curd firmness; $\mathrm{CF}_{\max }=$ maximum curd firmness achieved within 45 min; $\mathrm{t}_{\max }=$ time at achievement of $\mathrm{CF}_{\max }$.

composition. The indirect effect of breed on $\mathrm{CF}_{\mathrm{t}}$ parameters due to breed differences in terms of dMY and quality was obtained by subtracting the breed variance yielded by model [3] from the breed variance obtained from model [2].

\section{RESULTS}

\section{Descriptive Statistics and Effect of Farm}

Descriptive statistics of yield traits, chemical composition, and $\mathrm{CF}_{\mathrm{t}}$ modeling parameters of individual goat milk samples are summarized in Table 1. Data were close to normal distribution (skewness ranged from -0.02 to 2.08 ), with some traits presenting a leptokurtic distribution $\left(\mathrm{k}_{\mathrm{CF}}\right.$ and $\left.\mathrm{k}_{\mathrm{SR}}\right)$.

Variance of farm on $\mathrm{CF}_{\mathrm{t}}$ model parameters of goat milk is shown in Table 2, together with the corresponding traits obtained on bovine (Bittante et al., 2015; Stocco et al., 2017) and ovine milk (Vacca et al., 2015). In comparison with the other species, the proportion of variance due to the farm was high for all parameters, around $30 \%$ for the 2 rate constants (curd firming and syneresis rates), $34 \%$ for $\mathrm{RCT}_{\text {eq }}, 27 \%$ for $\mathrm{t}_{\max }$, and al-

Table 2. Farm effect on curd firming over time $\left(\mathrm{CF}_{\mathrm{t}}\right)$ equation parameters and derived traits on individual goat, bovine, and ovine milk samples

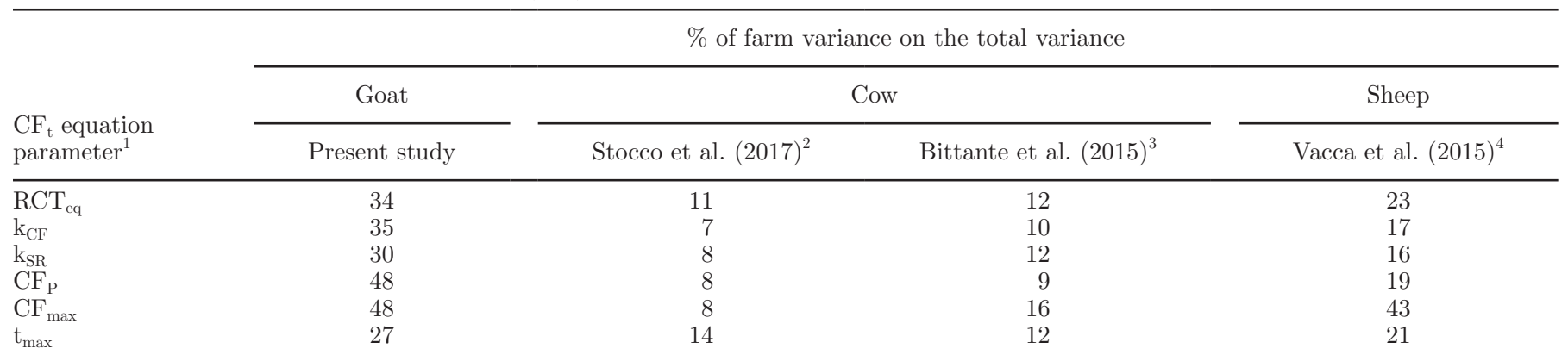

${ }^{1} \mathrm{RCT}_{\mathrm{eq}}=$ rennet coagulation time estimated according to $\mathrm{CF}_{\mathrm{t}}$ modeling; $\mathrm{k}_{\mathrm{CF}}=$ curd firming instant rate constant; $\mathrm{CF}_{\mathrm{P}}=$ asymptotic potential curd firmness; $\mathrm{k}_{\mathrm{SR}}=$ syneresis instant rate constant; $\mathrm{CF}_{\max }=$ maximum curd firmness achieved within 45 min; $\mathrm{t}_{\max }=$ time at achievement of $\mathrm{CF}_{\max }$.

${ }^{2}$ Stocco et al. $(2017)=41$ multi-breed herds; Holstein-Friesian, Brown Swiss, Jersey, Simmental, Rendena, and Alpine Grey breeds; herd was considered within herd productivity level.

${ }^{3}$ Bittante et al. $(2015)=85$ single-breed herds; Brown Swiss breed; herd was considered within dairy system.

${ }^{4}$ Vacca et al. $(2015)=23$ single-breed flocks; Sarda breed; flock was considered within flock size. 
Table 3. Least squares means of parity effect and orthogonal contrasts ( $F$-value) of curd firming over time $\left(\mathrm{CF}_{\mathrm{t}}\right)$ equation parameters and derived traits

\begin{tabular}{|c|c|c|c|c|c|}
\hline \multirow{2}{*}{$\begin{array}{l}\mathrm{CF}_{\mathrm{t}} \text { equation } \\
\text { parameter }^{1}\end{array}$} & \multicolumn{3}{|c|}{ Parity (LSM) } & \multicolumn{2}{|c|}{ Parity contrast ( $F$-value) } \\
\hline & 1st-2nd & $3 \mathrm{rd}-4 \mathrm{th}$ & $\geq 5$ th & 1st-2nd vs. $\geq 3$ rd & 3rd- -4 th vs. $\geq 5$ th \\
\hline $\mathrm{RCT}_{\mathrm{eq}}, \min$ & 13.2 & 13.9 & 14.1 & $7.9^{* *}$ & 0.4 \\
\hline $\mathrm{k}_{\mathrm{CF}}, \% / \min$ & 18.0 & 18.5 & 19.0 & 2.6 & 0.6 \\
\hline $\mathrm{k}_{\mathrm{SR}}, \% / \mathrm{min}$ & 0.63 & 0.65 & 0.64 & 0.4 & 0.1 \\
\hline $\mathrm{CF}_{\mathrm{P}}, \mathrm{mm}$ & 46.5 & 45.1 & 43.1 & $15.4^{* * *}$ & $10.0^{* *}$ \\
\hline $\mathrm{CF}_{\max }, \mathrm{mm}$ & 41.1 & 39.9 & 38.2 & $15.4^{* * *}$ & $10.0^{* *}$ \\
\hline$t_{\max }, \min$ & 39.3 & 38.7 & 38.3 & 0.9 & 0.3 \\
\hline
\end{tabular}

${ }^{1} \mathrm{RCT}_{\mathrm{eq}}=$ rennet coagulation time estimated according to $\mathrm{CF}_{\mathrm{t}}$ modeling; $\mathrm{k}_{\mathrm{CF}}=$ curd firming instant rate constant; $\mathrm{k}_{\mathrm{SR}}=$ syneresis instant rate constant $\mathrm{CF}_{\mathrm{P}}=$ asymptotic potential curd firmness; $\mathrm{CF}_{\max }=$ maximum curd firmness achieved within $45 \mathrm{~min} ; \mathrm{t}_{\max }=$ time at achievement of $\mathrm{CF}_{\max }$.

$* * P<0.01 ; * * * P<0.001$.

most $50 \%$ for curd firmness traits $\left(\mathrm{CF}_{\mathrm{P}}\right.$ and $\left.\mathrm{CF}_{\max }\right)$. Because $\mathrm{CF}_{\mathrm{P}}$ was calculated from $\mathrm{CF}_{\max }$, these results are directly related to $\mathrm{CF}_{\max }$ values.

\section{Effects of Parity and DIM}

Least squares means of parity and related orthogonal contrasts for $\mathrm{CF}_{\mathrm{t}}$ equation parameters are reported in Table 3. Milk from goats belonging to the first class of parity (primiparous and secondiparous goats) was characterized by shorter $\mathrm{RCT}_{\mathrm{eq}}$, compared with goats with 3 or more parities, together with higher potential $\left(\mathrm{CF}_{\mathrm{P}}\right)$ and maximum curd firmness $\left(\mathrm{CF}_{\max }\right)$.

The effect of DIM was significant for almost all the $\mathrm{CF}_{\mathrm{t}}$ parameters (Table 4). The $\mathrm{RCT}_{\text {eq }}$ decreased linearly from the first to the last class of DIM of about 1 min, and $\mathrm{t}_{\max }$ shortened by $4.5 \mathrm{~min}$ during the lactation period. This was mostly due to the increase of $\mathrm{k}_{\mathrm{CF}}$ parameter $\left(+4.2 \% \times \mathrm{min}^{-1}\right)$ during lactation. Also $\mathrm{CF}_{\mathrm{P}}$ and $\mathrm{CF}_{\max }$ showed an increase during lactation, whereas $\mathrm{k}_{\mathrm{SR}}$ was slightly affected by DIM with a cubic trend.

\section{Effect of Breed}

Least squares means of breed effect, corrected for the other factors of variation included in model [1] (farms, parity, and DIM of the goats, and pendulum of the instrument) are reported in Table 5. On average, no differences were shown between the breeds of Alpine and Mediterranean type, with the exception of curd-firming rate constant $\left(\mathrm{k}_{\mathrm{CF}}\right)$, lower for the Alpine. Within the 2 Alpine (Sa vs. CA), weak differences were found for the asymptotic potential curd firmness $\left(\mathrm{CF}_{\mathrm{P}}\right)$ and maximum curd firmness $\left(\mathrm{CF}_{\max }\right)$, higher for $\mathrm{CA}$. Within the 4 breeds of Mediterranean type, large differences were observed for $\mathrm{CF}_{\mathrm{P}}$ and $\mathrm{CF}_{\max }$ traits, lower in MG breed compared with the 3 Italian (Ma, Sr, and SP). Finally, curd-firming traits were lower in Ma than in the 2 autochthonous breeds of the Sardinia island, $\mathrm{Sr}$ and SP, whereas no difference was observed between these 2 last breeds.

\section{DISCUSSION}

\section{Modeling the Coagulation Ability of Goat Milk}

In milk of all dairy species, curd firmness (CF) initially increases to a maximum value and then tends to decrease because of the expulsion of whey from curd, known as syneresis (Calvo and Balcones, 2000). The 4-parameter model derives from a revision of a previous model (3-parameter model; Bittante, 2011), which did not fit observations in the descending part of the coagulation process. According to that model, the $\mathrm{CF}$ of any coagulated sample is a function of the maximum potential $\mathrm{CF}\left(\mathrm{CF}_{\mathrm{P}}\right)$, which is conceptually independent from both test duration and RCT (unlike the traditional trait $\mathrm{a}_{30}$ ), and of the 2 opposing phenomena of the speed of curd firming and syneresis $\left(\mathrm{k}_{\mathrm{CF}}\right.$ and $\mathrm{k}_{\mathrm{SR}}$, respectively). The parameter $\mathrm{k}_{\mathrm{CF}}$ describes the shape of the curve from the time of milk gelation to infinity and is assumed to increase CF toward the asymptotic value of $\mathrm{CF}_{\mathrm{P}}$, whereas $\mathrm{k}_{\mathrm{SR}}$ is assumed to decrease $\mathrm{CF}$ toward a null asymptotic value, modeling the curve in a declining region. Indeed, the parameter $\mathrm{k}_{\mathrm{SR}}$ measures the reduction of $\mathrm{CF}$ and describes the expulsion of whey during syneresis and the increased floating of curd in the vessel. So, in the initial phase of the test, the first rate constant prevails over the second, so that $\mathrm{CF}_{\mathrm{t}}$ increases to a point in time $\left(\mathrm{t}_{\max }\right)$ at which the effects of the 2 parameters are equal but opposite in sign; this is when $\mathrm{CF}_{\mathrm{t}}$ attains its maximum level $\left(\mathrm{CF}_{\max }\right)$. Thereafter, $\mathrm{CF}_{\mathrm{t}}$ decreases, tending toward a null value due to the effect of curd syneresis. The $\mathrm{RCT}_{\text {eq }}$ parameter conceptually corresponds to the traditional RCT measure, but it is estimated together with the other model's parameters using all available data. Mean val- 
Table 4. Least squares means of DIM effect and orthogonal contrasts ( $F$-value) of curd firming over time $\left(\mathrm{CF}_{\mathrm{t}}\right)$ equation parameters and derived traits

\begin{tabular}{|c|c|c|c|c|c|c|c|}
\hline \multirow{2}{*}{$\begin{array}{l}\mathrm{CF}_{\mathrm{t}} \text { equation } \\
\text { parameter }^{1}\end{array}$} & \multicolumn{4}{|c|}{ DIM (LSM) } & \multicolumn{3}{|c|}{ DIM contrast ( $F$-value) } \\
\hline & $<80$ & $80-120$ & $121-160$ & $>160$ & Linear & Quadratic & Cubic \\
\hline $\mathrm{RCT}_{\text {eq }}, \min$ & 14.5 & 13.4 & 13.5 & 13.4 & $5.2^{*}$ & 2.7 & 1.5 \\
\hline $\mathrm{k}_{\mathrm{CF}}, \% / \min$ & 16.5 & 17.7 & 18.9 & 20.7 & $29.7^{* * *}$ & 0.4 & 0.2 \\
\hline $\mathrm{k}_{\mathrm{SR}}, \% / \mathrm{min}$ & 0.63 & 0.58 & 0.68 & 0.67 & 2.1 & 0.4 & $4.1^{*}$ \\
\hline $\mathrm{CF}_{\mathrm{P}}, \mathrm{mm}$ & 42.7 & 44.9 & 45.5 & 46.4 & $12.6^{* * *}$ & 1.3 & 0.5 \\
\hline $\mathrm{CF}_{\max }, \mathrm{mm}$ & 37.8 & 39.8 & 40.3 & 41.0 & $12.6^{* * *}$ & 1.3 & 0.5 \\
\hline $\mathrm{t}_{\max }, \min$ & 40.8 & 38.9 & 39.1 & 36.3 & $10.9^{* *}$ & 0.4 & 2.4 \\
\hline
\end{tabular}

${ }^{1} \mathrm{RCT}_{\mathrm{eq}}=$ rennet coagulation time estimated according to $\mathrm{CF}_{\mathrm{t}}$ modeling; $\mathrm{k}_{\mathrm{CF}}=$ curd firming instant rate constant; $\mathrm{k}_{\mathrm{SR}}=$ syneresis instant rate constant; $\mathrm{CF}_{\mathrm{P}}=$ asymptotic potential curd firmness; $\mathrm{CF}_{\max }=$ maximum curd firmness achieved within $45 \mathrm{~min} ; \mathrm{t}_{\max }=$ time at achievement of $\mathrm{CF}_{\max }$.

$* P<0.05 ; * * P<0.01 ; * * * P<0.001$.

ues of the RCT measured using the Formagraph (Vacca et al., 2018) and $\mathrm{RCT}_{\mathrm{eq}}$ estimated in the present study were 13.2 and $13.9 \mathrm{~min}$, respectively, with a correlation coefficient at 0.99. Application of the model to the lactodynamographic layout permits the estimation of the 4 parameters, but also of the maximum $\mathrm{CF}$ value $\left(\mathrm{CF}_{\max }\right)$, and the time interval from rennet addition to the attainment of the maximum $\mathrm{CF}\left(\mathrm{t}_{\max }\right)$, which also incorporates the RCT.

The 4-parameter $\mathrm{CF}_{\mathrm{t}}$ model adapted very well to the description of the coagulation, curd firming, and syneresis processes of goat milk. Fitting statistics of this nonlinear model were very high, with coefficient of determination of all individual equations on average at $0.997( \pm 0.009)$. Similar values were obtained also on bovine (Stocco et al., 2017) and ovine species (Vacca et al., 2015) even though the average pattern of $\mathrm{CF}_{\mathrm{t}}$ curves is very different among species.

To fully appreciate these large differences, we have plotted in Figure 1 the $\mathrm{CF}_{\mathrm{t}}$ curve obtainable from average equation parameters obtained in the present study from 1,272 goat milk samples, together with those obtained from 1,508 bovine (Stocco et al., 2017) and 1,121 sheep (Vacca et al., 2015) milk samples. All o the surveys were carried out using the same type of instrument (Formagraph), experimental conditions (sample preparation, quantity and activity of rennet, temperature, test time, and traits recorded) and very similar statistical models. Milk from goats has a coagulation time $\left(\mathrm{RCT}_{\text {eq }}\right)$ and time to attain $\mathrm{CF}_{\max }\left(\mathrm{t}_{\max }\right)$ intermediate between sheep and cow milk, and $\mathrm{CF}_{\max }$ much lower than the other 2 species. It is possible to observe that $t_{\max }$ is recorded about $20 \mathrm{~min}$ after rennet addition for ovine, slightly longer for caprine, and much longer for bovine milk, so that the traditional $\mathrm{a}_{30}$ trait is measured in the decreasing, stable, and increasing phases of $\mathrm{CF}_{\mathrm{t}}$ curve for these 3 species, respectively.

Figure 1 also shows that the measurements of RCT, $\mathrm{k}_{20}$, and $\mathrm{a}_{30}$ are not fully informative of the actual pattern and characteristics of technological properties of

Table 5. Least squares means of breed effect and orthogonal contrasts ( $F$-value) of curd firming over time $\left(\mathrm{CF}_{\mathrm{t}}\right)$ equation parameters and derived traits ${ }^{1}$

\begin{tabular}{|c|c|c|c|c|c|c|c|c|c|c|c|}
\hline \multirow{2}{*}{$\begin{array}{l}\mathrm{CF}_{\mathrm{t}} \text { equation } \\
\text { parameter }^{2}\end{array}$} & \multicolumn{6}{|c|}{ Breed (LSM) } & & & & & \\
\hline & \multicolumn{2}{|c|}{ Alpine type } & \multicolumn{4}{|c|}{ Mediterranean type } & \multicolumn{5}{|c|}{ Breed contrast ( $F$-value) } \\
\hline $\mathrm{RCT}_{\mathrm{eq}}, \min$ & 13.7 & 15.0 & 13.4 & 12.5 & 13.7 & 13.9 & 2.0 & 2.7 & 0.0 & 1.5 & 0.1 \\
\hline $\mathrm{CF}_{\mathrm{P}}, \mathrm{mm}$ & 40.7 & 44.9 & 41.5 & 41.1 & 50.4 & 50.8 & 2.9 & $5.2^{*}$ & $9.7^{* *}$ & $11.3^{* * *}$ & 0.1 \\
\hline $\mathrm{CF}_{\max }, \mathrm{mm}$ & 36.0 & 39.7 & 36.8 & 36.4 & 44.6 & 45.0 & 2.9 & $5.2^{*}$ & $9.7^{* *}$ & $11.3^{* * *}$ & 0.1 \\
\hline$t_{\max }, \min$ & 39.3 & 43.0 & 40.5 & 37.5 & 37.4 & 35.0 & 3.6 & 3.2 & 3.5 & 0.2 & 1.9 \\
\hline
\end{tabular}

${ }^{1} \mathrm{Sa}=$ Saanen; $\mathrm{CA}=$ Camosciata delle Alpi; MG = Murciano-Granadina; Ma = Maltese; $\mathrm{Sr}=$ Sarda; and SP = Sarda Primitiva.

${ }^{2} \mathrm{RCT}_{\mathrm{eq}}=$ rennet coagulation time estimated according to $\mathrm{CF}_{\mathrm{t}}$ modeling; $\mathrm{k}_{\mathrm{CF}}=$ curd firming instant rate constant; $\mathrm{k}_{\mathrm{SR}}=$ syneresis instant rate constant; $\mathrm{CF}_{\mathrm{P}}=$ asymptotic potential curd firmness; $\mathrm{CF}_{\max }=$ maximum curd firmness achieved within 45 min; $\mathrm{t}_{\max }=$ time at achievement of $\mathrm{CF}_{\max }$.

${ }^{*} P<0.05$; ${ }^{* *} P<0.01$; *** $P<0.001$. 


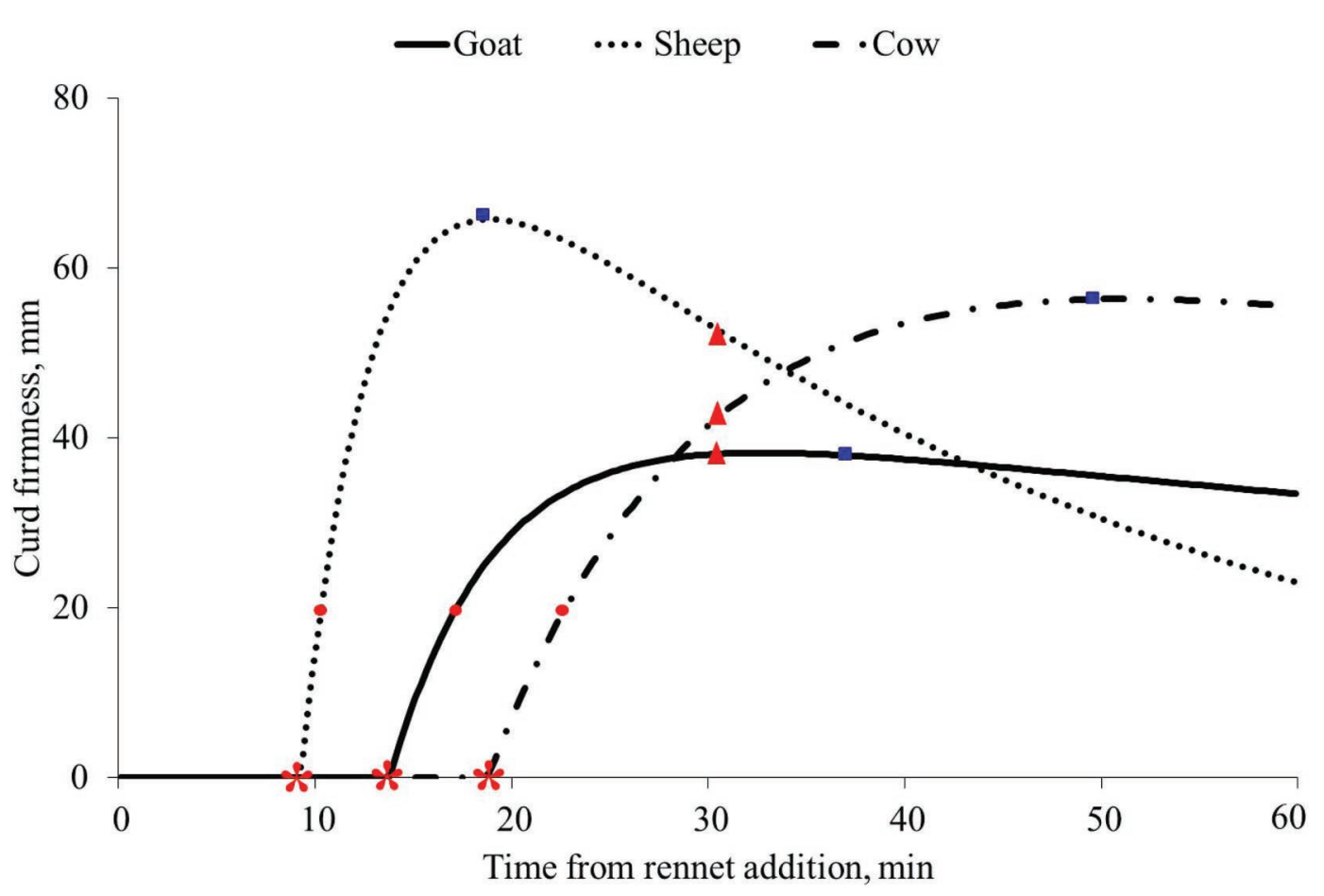

Figure 1. Pattern of curd firmness over time $\left(\mathrm{CF}_{\mathrm{t}}\right)$ and maximum curd firmness (squares $\left.=\mathrm{CF}_{\max }\right)$ of milk samples from the 6 breeds of goats of the present study, from 6 breeds of cows (Holstein-Friesian, Brown Swiss, Jersey, Simmental, Rendena, and Alpine Grey; Stocco et al., 2017), and from Sarda ewes (Vacca et al., 2015), and traditional single-point parameters ${ }^{*}=$ rennet coagulation time; circles $=$ curd-firming time $\left(\mathrm{k}_{20}\right)$; triangles $=$ curd firmness $\left.\left(\mathrm{a}_{30}\right)\right]$. Color version available online.

milk from the 3 species. The $\mathrm{k}_{20}$ interval presents the same chronological order for the species observed for RCT (i.e., sheep, goat, and cow), but the differences among $\mathrm{a}_{30}$ traits are not very large so that it could be imagined if we consider that the curve of the 3 species would be similar but delayed, starting from sheep, to goats, and to cow milk. The $\mathrm{CF}_{\mathrm{t}}$ modeling offers a completely different picture with $\mathrm{CF}_{\mathrm{P}}$ and $\mathrm{CF}_{\max }$ much larger for sheep, intermediate for cow, and smaller for goat milk; $\mathrm{k}_{\mathrm{CF}}$ much larger for ovine, intermediate for goat, and smaller for cow milk; and finally, $\mathrm{k}_{\mathrm{SR}}$ very rapid for sheep, slow for goats, and almost null for cow milk (Calvo and Balcones, 2000). This information may be important because goat milk and cheese, especially in Spain, Greece, and Portugal, are competitors of sheep dairy products (Dubeuf, 2005). Hence, the production of dairy products using mixtures of goat, cow and sheep milk could also be an interesting and feasible opportunity for the enhancement of the cheese-making properties.

\section{Effect of Farm}

In the literature, the effect of farming system has been widely considered in goat species (Ruiz et al., 2009; Mohlatlole et al., 2015), but not in relation to coagulation, curd firming, and syneresis of milk. Although goats have a strong ability to adapt to different environmental conditions (Silanikove, 2000), the farming system is important because it interacts with the genetic type of the animal, the production target (milk for consumption vs. cheese-making) and profitability of the methods (extensive vs. intensive). In papers regarding goats milk quality and traditional MCP, the effect of farm in statistical models was often considered as a fixed factor (Zullo et al., 2005; Pazzola et al., 2014b). Similarly to the present study, in our recent surveys on $\mathrm{CF}_{\mathrm{t}}$ modeling in ovine and bovine species (Vacca et al., 2015; Stocco et al., 2017), we treated farm as a random factor; therefore, the corresponding variance component could be estimated and expressed as a proportion of total variance. The comparison among the surveys on the 3 species, summarized in Table 2, shows great differences among them. Indeed, the effect of farms represented a very large source of variation of all $\mathrm{CF}_{\mathrm{t}}$ parameters in the case of goats (27 to $48 \%$ of total variance), whereas it was very limited for cows (7 to $16 \%$ ) and intermediate for sheep (16 to 43\%). Further studies are needed to investigate if the large farm effect recorded on goats depends on feeding system, environmental effects, or genetic intra-farm selection. We can speculate that in the present study, the farm ef- 


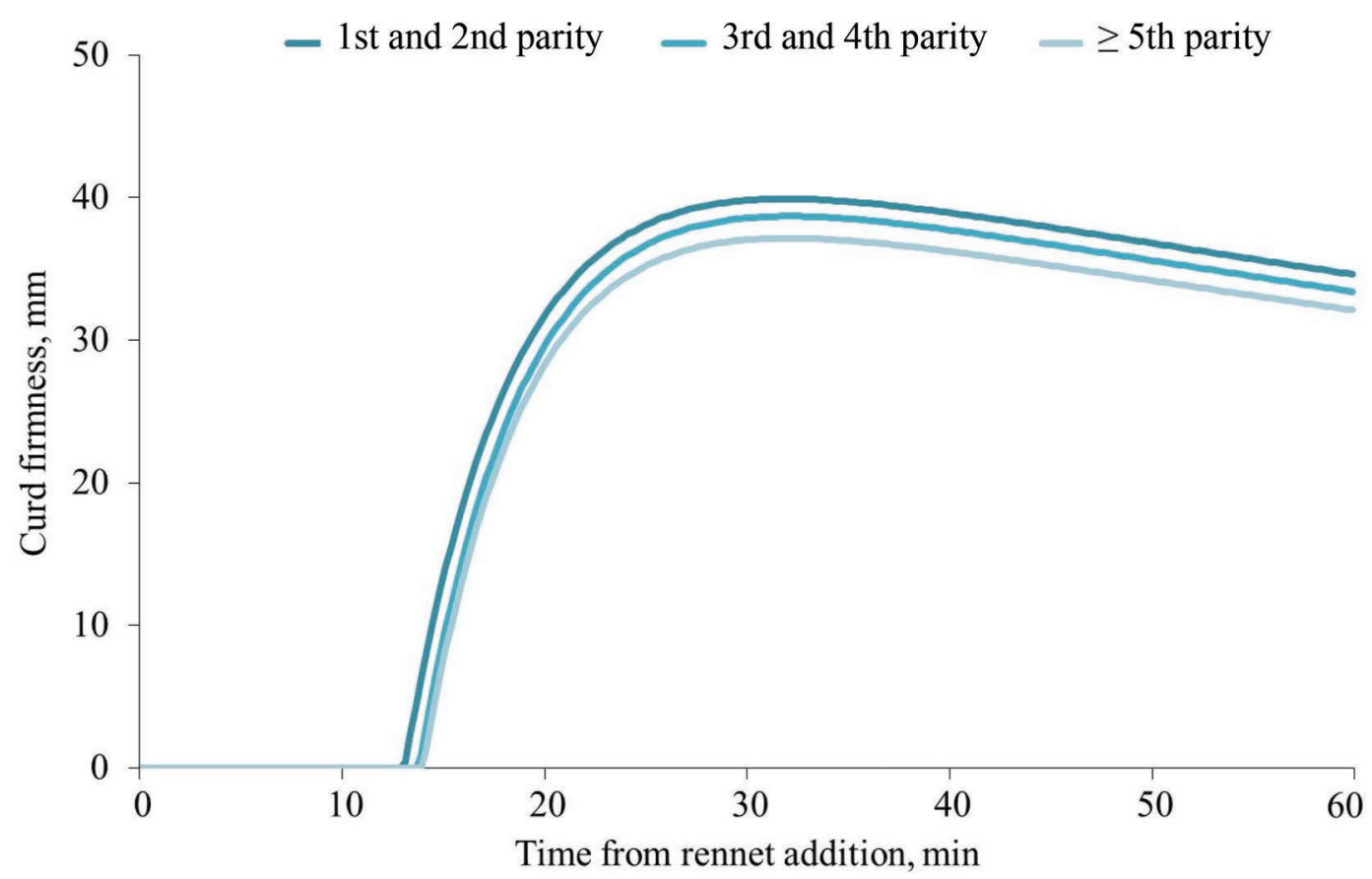

Figure 2. Pattern of curd firmness over time equation parameters and derived traits of milk samples across classes of parity. Color version available online.

fect, as an important source of variation for $\mathrm{CF}_{\mathrm{t}}$ model parameters, was probably attributable to the marked differences among farming systems (Dubeuf, 2005), whereas in the cited studies about ovine and bovine (Vacca et al., 2015; Stocco et al., 2017), these were more homogeneous among the farms. It is important to consider that the territory where milk samples were collected, Sardinia, has been characterized for decades by extensive or semi-extensive goat farming systems (Boyazoglu and Morand-Fehr, 2001; Dubeuf, 2005). The introduction of specialized dairy breeds with the aim to select animals for higher milk yield led to the adoption of intensive or semi-intensive systems (Vacca et al., 2016), and the consequent wide diversification of the goat farming systems.

\section{Individual Animal Factors}

Figure 2 shows the combined effects of parity on $\mathrm{CF}_{t}$ modeling parameters. The shorter coagulation time and higher values of CF confirmed the slight superiority of technological properties of milk from first and second parity goats over the older ones, in accordance with the results found for traditional MCP in goats (Vacca et al., 2018) and modeled $\mathrm{CF}_{\mathrm{t}}$ patterns in sheep (Vacca et al., 2015). These results seemed not to derive from modification in milk composition occurring at increasing number of parity, especially fat and protein, because no differences were previously evidenced for the same data set in Vacca et al. (2018). In bovine, parity has often been considered in statistical models (Bittante et al., 2015; Stocco et al., 2017), with a significant decrease of $\mathrm{CF}$ traits $\left(\mathrm{CF}_{\mathrm{P}}\right.$ and $\left.\mathrm{CF}_{\max }\right)$ across parity levels, in agreement with the results of the present study.

The pattern of $\mathrm{CF}_{\mathrm{t}}$ modeling after rennet addition of individual goat milk samples according to stage of lactation is depicted in Figure 3. The effect of DIM was very important for all the $\mathrm{CF}_{\mathrm{t}}$ parameters, excluding syneresis rate constant. Milk produced at the end of lactation has a better technological quality than milk from the first stages, in contrast with results found for bovine milk (Stocco et al., 2017). Indeed, in the first $80 \mathrm{~d}$ of lactation milk was characterized by the longest values of $\mathrm{RCT}_{\mathrm{eq}}$ and the weakest $\mathrm{CF}_{\mathrm{P}}$ and $\mathrm{CF}_{\max }$ values. The speed of curd firming was linearly accelerated from the beginning to the end of lactation period, so that a higher curd-firming rate $\left(\mathrm{k}_{\mathrm{CF}}\right)$ led to higher $\mathrm{CF}$ in a shorter time during lactation, which is represented by the parameter $t_{\max }$. These differences across DIM could be partially explained by the differences in milk composition (Vacca et al., 2018), in accordance with previous studies investigating the relationship between distinct traits of milk composition and coagulation in goats (Calvo and Balcones, 2000; Zullo et al., 2005), but further studies are needed. Syneresis was slightly affected by a cubic trend during DIM, with the low- 


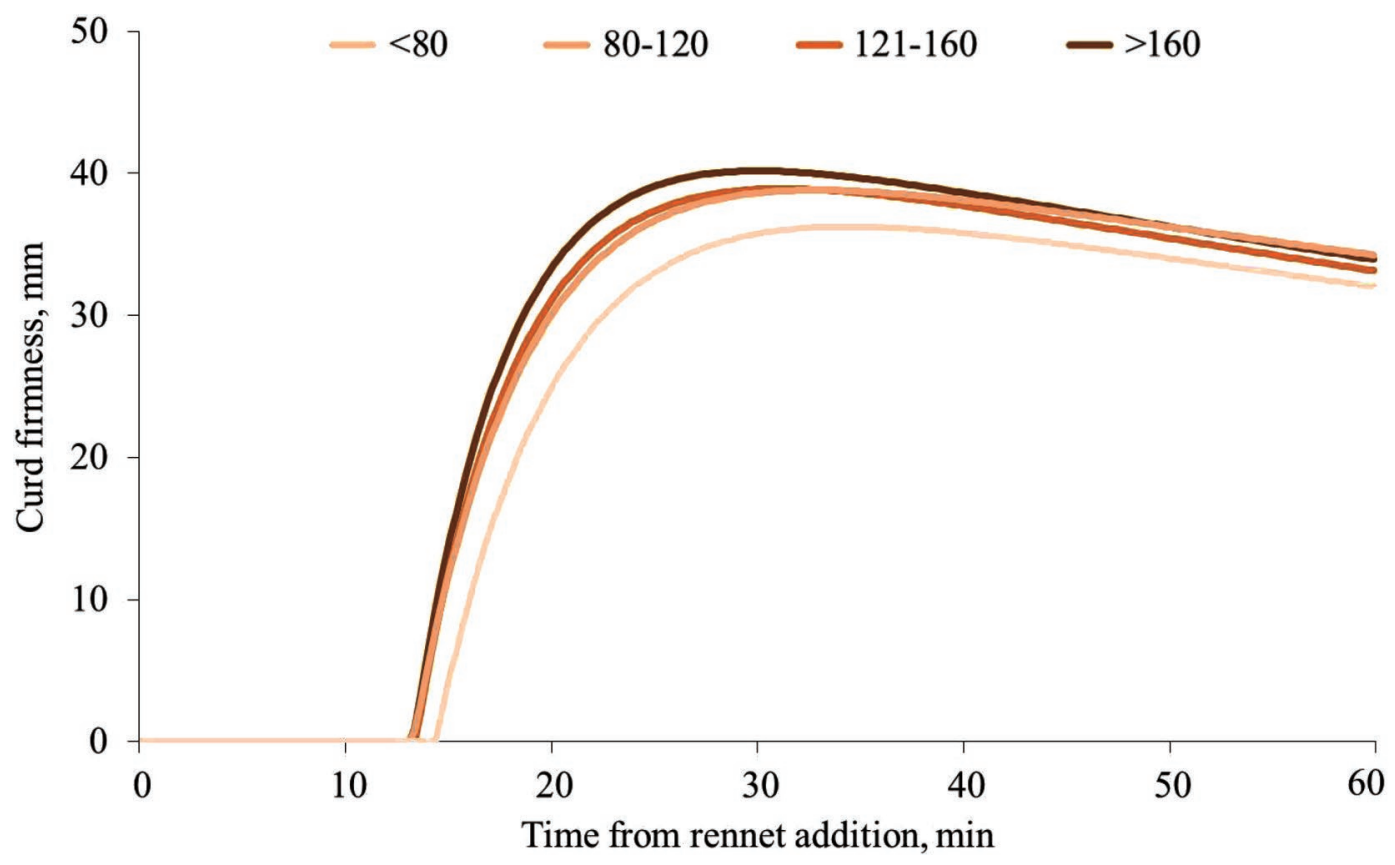

Figure 3. Pattern of curd firmness over time equation parameters and derived traits of milk samples according to stage of lactation (DIM). Color version available online.

est value between 80 and 120 DIM, and increasing thereafter. Because the expulsion of the whey from the curd is mainly controlled by the protein content in milk (Emmons et al., 2003) and by the rearrangement of the network of casein micelles (Dejmek and Walstra, 2004), it can be supposed that the cubic pattern of syneresis rate constant followed the protein content of milk samples (data not shown). Indeed, previous results obtained from the same data set (Vacca et al., 2018) indicates that protein content of goat milk shows the lowest value between 80 and 120 DIM.

\section{Effect of Breed}

No previous research paper has studied $\mathrm{CF}_{\mathrm{t}}$ parameters obtained from a large sample size of goats belonging to 6 breeds. Knowledge of the 4-parameter model allowed us to shape the complete pattern of coagulation, curd firming, and syneresis, and to test its contribution to the differences observed among the different breeds.

Breed exerted an important effect on the time evolution of technological properties of goat milk. The effect of breed on the pattern of coagulation, curd firming, and syneresis is summarized in Figure 4, which shows the curves obtained from the least squares means of $\mathrm{CF}_{\mathrm{t}}$ equation parameters for the 6 breeds of goats analyzed.

Large differences in the $\mathrm{CF}_{\mathrm{t}}$ equations are observed also among 6 breeds of cows (Stocco et al., 2017), with the most favorable results showed by Jerseys, the least by Holsteins, and intermediate pattern by cows of Alpine origin (Brown Swiss, Simmental, Rendena, and Alpine Grey). In the case of ovine species, the only comparison regarded 3 breeds autochthonous of the northeastern Italian Alps that show modest differences from each other (Bittante et al., 2014).

Goat breeds of the Mediterranean type, on average, did not show great differences of the coagulation pattern in comparison with the Alpine type, which was characterized by a slower increase of the $\mathrm{CF}$ after rennet addition. A firmer curd improves cheese yield by encouraging retention of milk components (Martin and Addeo, 1996), so it can be considered highly related to cheese yield, quality, and economic returns (Clark and Sherbon, 2000).

Between the 2 breeds of Alpine type, the only evident difference was observed in the second phase of the curve because of a slightly larger maximum and asymptotical $\mathrm{CF}$ of milk from CA goats, whereas in previous studies on traditional MCP no difference is found between the 2 breeds (Alloggio et al., 2000; Vacca et al., 2018). These 2 breeds are excellent dairy specialized types, and this made them a popular choice for goat dairy plants with a focus on milk rather than cheese (Niemann, 2013). In the available literature, milk from the CA breed showed better coagulation properties (shorter RCT, faster $\mathrm{k}_{20}$, and higher $\mathrm{CF}$ ) than the Sa, and no significant differences in milk composition (Ambrosoli et al., 1988). On the contrary, in Clark and Sherbon (2000) milk from Sa 


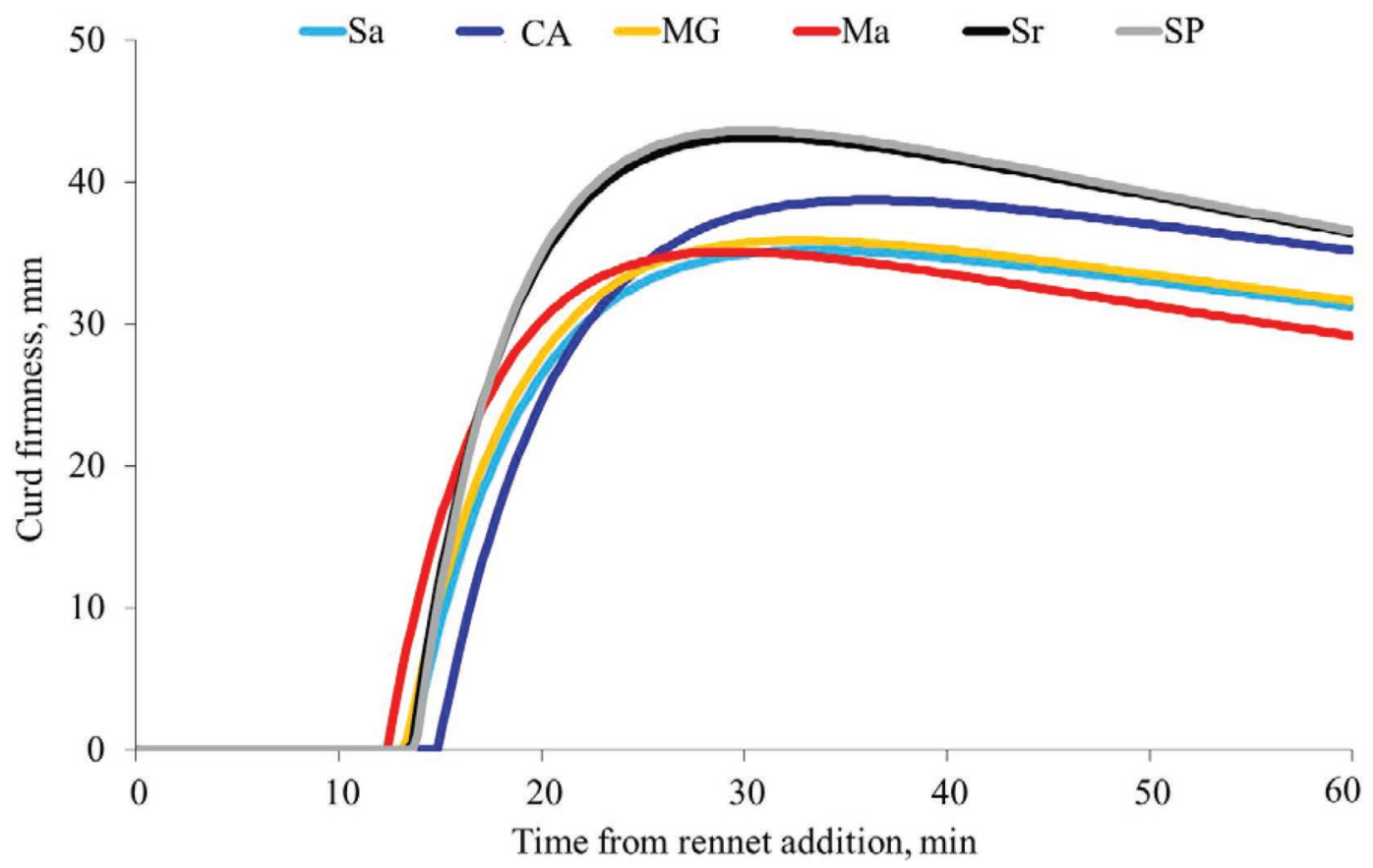

Figure 4. Pattern of curd firmness over time equation parameters and derived traits of milk samples for the 6 breeds of goats. Sa $=$ Saanen; $\mathrm{CA}=$ Camosciata delle Alpi; $\mathrm{MG}=$ Murciano-Granadina; $\mathrm{Ma}=$ Maltese; $\mathrm{Sr}=$ Sarda; and $\mathrm{SP}=$ Sarda Primitiva. Color version available online.

goats exhibited significantly higher $\mathrm{SNF}$ and $\alpha_{\mathrm{S} 1}-\mathrm{CN}$, but no differences in coagulation properties.

Milk from MG exhibited an evolution of coagulation pattern almost similar to that of the Sa goats, and not much different from that of Ma. This result suggested that that the final destination of milk from MG should be more suitable as milk for consumption, rather than for cheese-making. However, comparisons among these dairy breeds in regard to cheese-making ability are not known and need to be further studied. Within the Italian breeds, the 2 autochthonous breeds from Sardinia (Sr and SP) exhibited technological pattern very different from all the other breeds. Their coagulation patterns were not due to differences in coagulation time, but to the rapidity of curd firming, the rapidity and entity of maximum $\mathrm{CF}$, and also for a distinct effect of syneresis.

The curves of milk from Sr and SP goats were not distinguishable, thus confirming the results observed for traditional MCP (Vacca et al., 2018). It should be said that $\mathrm{Sr}$ is a large and somewhat heterogeneous goat population, and SP is considered the original ancestral source. Sarda goats present a large morphological variability that show frequent crossbreeding in the past with several other goat strains, and particularly with Ma goats (Usai et al., 2006). In a previous large survey on morphological variability of the $\mathrm{Sr}$ we have not found appreciable linking between some charac- teristics typical of Ma breed (polledness, long hanging ears, mainly white coat, and pear-shaped udders) with milk yield and quality, with the partial exception of ear length on milk contents and udder shape on SCS (Vacca et al., 2016). The present study showed that, on the basis of milk technological properties, the Sr breed is weakly linked with the Ma, but almost identical to its ancestral SP source.

Because this is the first study focusing on $\mathrm{CF}_{\mathrm{t}}$ parameters of several goat milk samples belonging to different breeds, we separated the overall effect of breed on different $\mathrm{CF}_{\mathrm{t}}$ parameters (Figure 5) from the direct effects of breed. The direct effect of breed, independent from its effects on milk yield and composition, was obtained by including the milk yield and quality (fat, protein, lactose, $\mathrm{pH}, \mathrm{SCS}$, and $\mathrm{LBC}$ ) in the statistical model. The differences between models [3] and [2] represent the indirect effects of breed due to changes in milk yield and composition. The results (not shown in tables) were consistent with those found by Vacca et al. (2018) for goat traditional MCP from the same data set, and by Stocco et al. (2017) on bovine species. The dMY did not affect any milk $\mathrm{CF}_{\mathrm{t}}$ trait. A favorable effect was exerted by fat $\left(P<0.001\right.$ for $\mathrm{RCT}_{\text {eq }}$ and $\mathrm{t}_{\max } ; P<0.01$ for the remaining parameters), protein $\left(P<0.001\right.$ for $\mathrm{RCT}_{\text {eq }}, \mathrm{CF}$ traits, and $\left.\mathrm{t}_{\max }\right)$, and lactose contents $\left(P<0.001\right.$ on all traits, $\mathrm{k}_{\mathrm{SR}}$ excluded $)$; the increment of milk $\mathrm{pH}, \mathrm{SCS}$, and LBC was unfavorably 


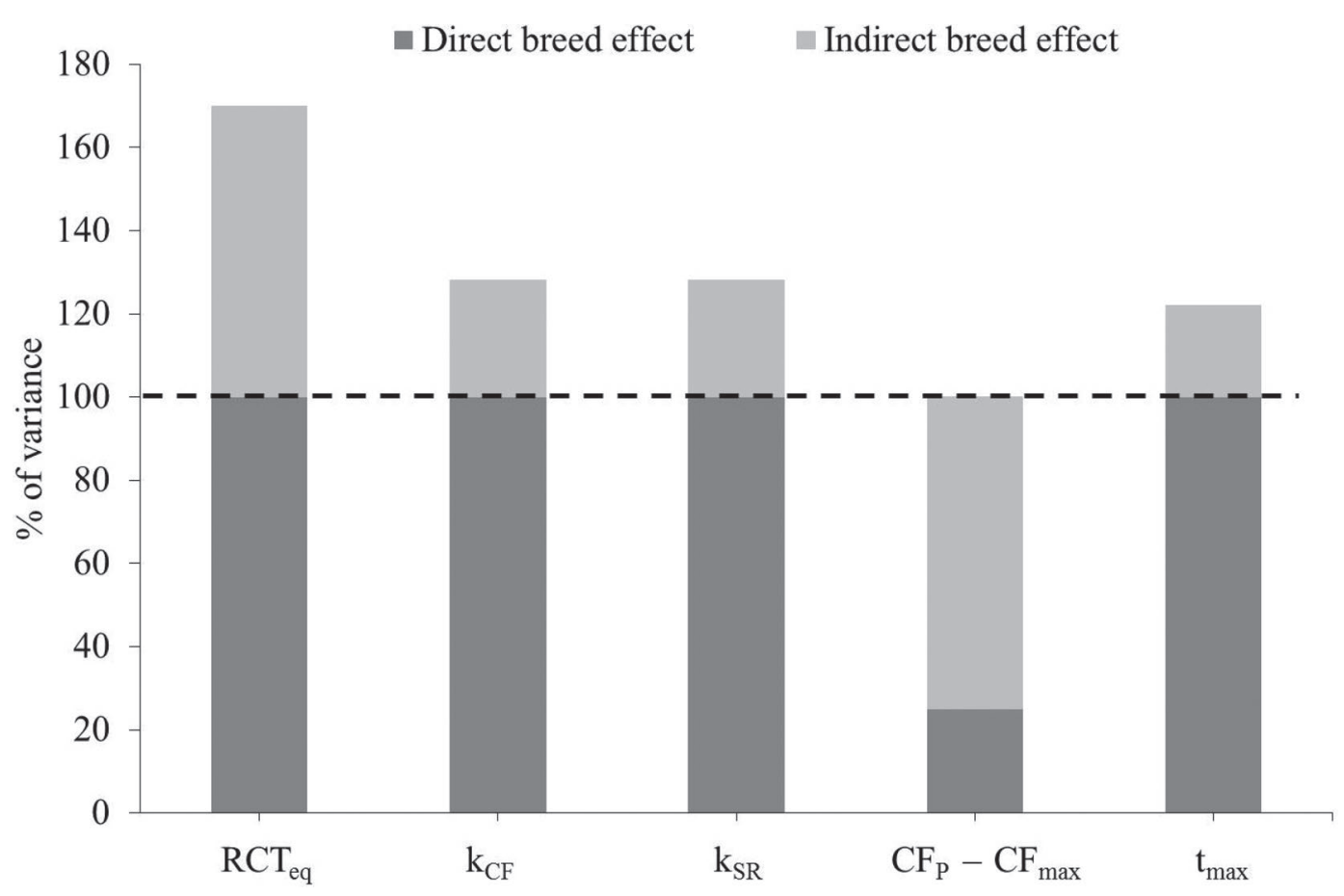

Figure 5. Proportion of total breed variance (assumed to be 100\%) of milk coagulation properties explained by direct breed effect (corrected for milk yield and quality traits) and by indirect breed effect (depending on the breed differences in milk yield and quality traits) on curd firming over time $\left(\mathrm{CF}_{\mathrm{t}}\right)$ equation parameters and derived traits. $\mathrm{RCT}_{\mathrm{eq}}=$ rennet coagulation time estimated according to $\mathrm{CF}_{\mathrm{t}}$ modeling; $\mathrm{k}_{\mathrm{CF}}=\mathrm{curd}$ firming instant rate constant; $\mathrm{k}_{\mathrm{SR}}=$ syneresis instant rate constant; $\mathrm{CF}_{\mathrm{P}}=$ asymptotic potential curd firmness; $\mathrm{CF}_{\max }=$ maximum curd firmness achieved within $45 \mathrm{~min} ; \mathrm{t}_{\max }=$ time at achievement of $\mathrm{CF}_{\max }$.

related to the majority of $\mathrm{CF}_{\mathrm{t}}$ traits $(P<0.001)$. The 2 autochthonous breeds from Sardinia were the least productive and with the best technological properties of milk. Hence, the absence of noticeable correlations between these traits seemed to draw a favorable scenario in which the improvement of the productivity of Sr goats could be achieved without losing its cheesemaking superiority.

Figure 5 summarizes, in terms of variance, the different importance of breed effects on $\mathrm{CF}_{\mathrm{t}}$ modeling parameters when it is corrected or not by milk yield and quality. It could be seen that in all $\mathrm{CF}_{\mathrm{t}}$ parameters, excluding $\mathrm{CF}_{\mathrm{P}}$ and $\mathrm{CF}_{\max }$, the direct effect of breed was greater after correction for milk yield and quality, and this is opposite to the results obtained in cattle (Stocco et al., 2017). A much lower direct effect of breed on $\mathrm{CF}_{\mathrm{t}}$ traits is reported by Vacca et al. (2018) for the traditional MCP, especially $\mathrm{a}_{30}$ and $\mathrm{a}_{45}$, as those parameters mainly depend on milk fat, protein (Clark and Sherbon, 2000; Farrell et al., 2004), and in particular some casein fractions (Selvaggi et al., 2014). However, an exhaustive knowledge about the relationships among traditional and modeled MCP, and the effect of milk composition is still lacking in goat species and needs to be developed.
The findings regarding the direct and indirect breed effects suggested that the marked differences found among breeds regarding $\mathrm{CF}_{\mathrm{t}}$ traits are likely imputable to the differences mediated by milk composition. On the other hand, the time traits (RCT and $\mathrm{k}_{20}$ ) and the 2 rate constants are affected more by individual factors of the goats (i.e., parity, DIM), including genetic ones, perhaps different from those controlling milk, fat, protein, and lactose secretions. The breed effect, when corrected for common (farm) and individual phenotypic sources of variation, may be considered the major genetic difference between animals and may be an indicator of possible genetic variation between and within populations.

\section{CONCLUSIONS}

In conclusion, the use of $\mathrm{CF}_{\mathrm{t}}$ modeling, based on all the information available after rennet addition and on extension of CF recording, allowed a better representation of the effects of the different factors examined on coagulation, curd firming, and syneresis of goat milk. These appeared to be much different from bovine and ovine species. In particular, the factors differentiating farms seemed to be very important for the coagulation 
ability of goat milk, differently from what has been seen in the other species. Large differences were also observed among breeds for $\mathrm{CF}_{\mathrm{t}}$ traits, especially within breeds of Mediterranean type. Even after correcting for milk yield and quality, these differences remained large. In particular, results confirmed the higher CF of Italian breeds than MG, and within the Italians, the superiority of the autochthonous goats from Sardinia. Further research is necessary at the cheese-making level to investigate the effects of farm, breed, and nongenetic factors to provide new insights into the differences among breed not mediated by milk yield and composition. This future scenario would also smooth the path for studies on the relationships between cheese-yield traits, $\mathrm{MCP}$, and $\mathrm{CF}_{\mathrm{t}}$ model parameters in goat milk.

\section{ACKNOWLEDGMENTS}

Research was funded by the Regional Government of Sardinia (Legge Regionale 7/2007; CUP J72I15000030007). The authors thank the farmers for giving access to their flocks; the AIPA/APA (Provincial Farmers Associations) of Cagliari, Nuoro, Sassari, and Oristano (Italy) and the firms Sepi Formaggi (Marrubiu, Italy) and L'Armentizia Moderna (Guspini, Italy) for their support in sample collection; and ARA Sardegna (Regional Farmers Association of Sardinia) for support in chemical milk analysis.

\section{REFERENCES}

Alloggio, V., F. Caponio, A. Pasqualone, and T. Gomes. 2000. Effect of heat treatment on the rennet clotting time of goat and cow milk. Food Chem. 70:51-55.

Ambrosoli, R., L. Di Stasio, and P. Mazzocco. 1988. Content of alpha S1-casein and coagulation properties in goat milk. J. Dairy Sci. $71: 24-28$.

Bertoni, G., L. Calamari, M. G. Maianti, and B. Battistotti. 2005. Milk for protected denomination of origin (PDO) cheeses: I. The main required features. Pages 217-228 in Indicators of Milk and Beef Quality. J. F. Hocquette and S. Gigli, ed. EAAP Publication 112. Wageningen Academic Publishers, Wageningen, the Netherlands.

Bittante, G. 2011. Modeling rennet coagulation time and curd firmness of milk. J. Dairy Sci. 94:5821-5832.

Bittante, G., C. Cipolat-Gotet, F. Malchiodi, E. Sturaro, F. Tagliapietra, S. Schiavon, and A. Cecchinato. 2015. Effect of dairy farming system, herd, season, parity and days in milk on modeling of the coagulation, curd firming and syneresis of bovine milk. J. Dairy Sci. 98:2759-2774.

Bittante, G., N. Cologna, A. Cecchinato, M. De Marchi, M. Penasa, F. Tiezzi, I. Endrizzi, and F. Gasperi. 2011. Monitoring of sensory attributes used in the quality payment system of Trentingrana cheese. J. Dairy Sci. 94:5699-5709.

Bittante, G., B. Contiero, and A. Cecchinato. 2013. Prolonged observation and modelling of milk coagulation, curd firming, and syneresis. Int. Dairy J. 29:115-123.

Bittante, G., E. Pellattiero, F. Malchiodi, C. Cipolat-Gotet, M. Pazzola, G. M. Vacca, S. Schiavon, and A. Cecchinato. 2014. Quality traits and modeling of coagulation, curd firming, and syneresis of sheep milk of Alpine breeds fed diets supplemented with rumenprotected conjugated fatty acid. J. Dairy Sci. 97:4018-4028.

Boyazoglu, J., and P. Morand-Fehr. 2001. Mediterranean dairy sheep and goat products and their quality. A critical review. Small Rumin. Res. 40:1-11.

Calvo, M. M., and E. Balcones. 2000. Some factors influencing the syneresis of bovine, ovine, and caprine milks. J. Dairy Sci. 83:17331739.

Cipolat-Gotet, C., A. Cecchinato, M. De Marchi, M. Penasa, and G. Bittante. 2012. Comparison between mechanical and near-infrared optical methods for assessing coagulation properties of bovine milk. J. Dairy Sci. 95:6806-6819.

Cipolat-Gotet, C., M. Pazzola, A. Ferragina, A. Cecchinato, M. L. Dettori, and G. M. Vacca. 2018. Technical note: Improving modeling of coagulation, curd firming and syneresis of sheep milk. J. Dairy Sci. 101:5832-5837. https://doi.org/10.3168/jds.2017-14256.

Clark, S., and J. W. Sherbon. 2000. AlphaS1-casein, milk composition and coagulation properties of goat milk. Small Rumin. Res. $38: 123-134$

Dejmek, P., and P. Walstra. 2004. The syneresis of rennet-coagulated curd. Pages 71-103 in Cheese: Chemistry, Physics and Microbiology. Vol. 1: General aspects. 3rd ed. P. Fox, P. McSweeney, T. Cogan, and T. Guinee, ed. Elsevier, Amsterdam, the Netherlands.

Dubeuf, J. P. 2005. Structural, market and organisational conditions for developing goat dairy production systems. Small Rumin. Res. 60:67-74.

Dubeuf, J. P., and J. Boyazoglu. 2009. An international panorama of goat selection and breeds. Livest. Sci. 120:225-231.

Emmons, D. B., C. Dubé, and H. W. Modler. 2003. Transfer of protein from milk to cheese. J. Dairy Sci. 86:469-485.

Farrell, H. M., R. Jimenez-Flores, G. T. Bleck, E. M. Brown, J. E. Butler, L. K. Creamer, C. L. Hicks, C. M. Hollar, K. F. Ng-KwaiHang, and H. E. Swaisgood. 2004. Nomenclature of the proteins of cows' milk-Sixth Revision. J. Dairy Sci. 87:1641-1674.

Malchiodi, F., A. Cecchinato, M. Penasa, C. Cipolat-Gotet, and G. Bittante. 2014. Milk quality, coagulation properties and curd firmness modeling of purebred Holsteins and first- and second-generation crossbred cows from Swedish Red, Montbéliarde, and Brown Swiss bulls. J. Dairy Sci. 97:4530-4541.

Marsoner, T., L. E. Vigl, F. Manck, G. Jaritz, U. Tappeiner, and E. Tasser. 2017. Indigenous livestock breeds as indicators for cultural ecosystem services: A spatial analysis within the Alpine Space. Ecol. Indic. https://doi.org/10.1016/j.ecolind.2017.06.046. In press.

Martin, B., J.-F. Chamba, J.-B. Coulon, and E. Perreard. 1997. Effect of milk chemical composition and clotting characteristics on chemical and sensory properties of Reblochon de Savoie cheese. J. Dairy Res. 64:157-162.

Martin, P., and F. Addeo. 1996. Genetic polymorphism of casein in the milk of goats and sheeps. Pages $45-58$ in Proc. IDF/Greek National Committee of IDF/CIRVAL. IDF Seminar "Production and utilization of ewe and goat milk." Creta, October 19-21, 1999.

McMahon, D. J., and R. J. Brown. 1982. Evaluation of Formagraph for comparing rennet solutions. J. Dairy Sci. 65:1639-1642.

Mohlatlole, R. P., E. F. Dzomba, and F. C. Muchadeyi. 2015. Addressing production challenges in goat production systems of South Africa: The genomics approach. Small Rumin. Res. 13:43-49.

Niemann, D. 2013. Raising Goats Naturally: The Complete Guide to Milk, Meat and More. New Society Publishers, Gabriola Island, Canada.

Park, Y. W., M. Juarez, M. Ramos, and G. F. W. Haenlein. 2007. Physico-chemical characteristics of goat and sheep milk. Small Rumin. Res. 68:88-113.

Pazzola, M., M. L. Dettori, C. Cipolat-Gotet, A. Cecchinato, G. Bittante, and G. M. Vacca. 2014a. Phenotypic factors affecting coagulation properties of milk from Sarda ewes. J. Dairy Sci. 97:72477257.

Pazzola, M., M. L. Dettori, E. Pira, A. Noce, P. Paschino, and G. M. Vacca. 2014b. Effect of polymorphisms at the casein gene cluster on milk renneting properties of the Sarda goat. Small Rumin. Res. 117:124-130. 
Pirisi, A., A. Lauret, and J. P. Dubeuf. 2007. Basic and incentive payments for goat and sheep milk in relation to quality. Small Rumin. Res. 68:167-178.

Ruiz, F. A., Y. Mena, J. M. Castel, C. Guinamard, N. Bossis, E. Caramelle-Holtz, M. Contu, M. Sitzia, and N. Fois. 2009. Dairy goat grazing systems in Mediterranean regions: A comparative analysis in Spain, France and Italy. Small Rumin. Res. 85:42-49.

Selvaggi, M., V. Laudadio, D. Cataldo, and V. Tufarelli. 2014. Major proteins in goat milk: An updated overview on genetic variability. Mol. Biol. Rep. 41:1035-1048.

Silanikove, N. 2000. The physiological basis of adaptation in goats to harsh environments. Small Rumin. Res. 35:181-193.

Silanikove, N., G. Leitner, U. Merin, and C. G. Prosser. 2010. Recent advances in exploiting goat's milk: Quality, safety and production aspects. Small Rumin. Res. 89:110-124.

Stocco, G., C. Cipolat-Gotet, T. Bobbo, A. Cecchinato, and G. Bittante. 2017. Breed of cow and herd productivity affect milk composition and modeling of coagulation, curd firming and syneresis. J. Dairy Sci. 100:129-145.

Stocco, G., C. Cipolat-Gotet, A. Cecchinato, L. Calamari, and G. Bittante. 2015. Milk skimming heating, acidification, lysozyme, and rennet affect the pattern, repeatability, and predictability of milk coagulation properties and of curd-firming model parameters: A case study of Grana Padano. J. Dairy Sci. 98:5052-5067.

Usai, M. G., S. Casu, G. Molle, M. Decandia, S. Ligios, and A. Carta. 2006. Using cluster analysis to characterize the goat farming system in Sardinia. Livest. Sci. 104:63-76.

Vacca, G. M., P. Paschino, M. L. Dettori, M. Bergamaschi, C. CipolatGotet, G. Bittante, and M. Pazzola. 2016. Environmental, morphological, and productive characterization of Sardinian goats and use of latent explanatory factors for population analysis. J. Anim. Sci. 94:3947-3957.

Vacca, G. M., M. Pazzola, M. L. Dettori, E. Pira, F. Malchiodi, C. Cipolat-Gotet, A. Cecchinato, and G. Bittante. 2015. Modeling of coagulation, curd firming and syneresis of milk from Sarda. J. Dairy Sci. 98:2245-2259.

Vacca, G. M., G. Stocco, M. L. Dettori, E. Pira, G. Bittante, and M. Pazzola. 2018. Milk yield, quality, and coagulation properties of 6 breeds of goats: Environmental and individual variability. J. Dairy Sci. 101:7286-7247. https://doi.org/10.3168/jds.2017-14111.

Zullo, A., C. M. A. Barone, L. Chianese, P. Colatruglio, M. Occidente, and D. Matassino. 2005. Protein polymorphisms and coagulation properties of Cilentana goat milk. Small Rumin. Res. 58:223-230. 